\title{
The Integration of the Dadia Eco-Tourism Area in SOUFLIDadia Settlement: Suggestions
}

\author{
By Plnar Kisa Ovali \\ Gildis Tachir
}

The tourism sector, which provides employment opportunities for the local population and which has significance in the economic development of the region, has entered into a rapid change process with the concept of "sustainability." The sector, which gives importance to the evaluation of the physical and socio-cultural environment within protection-usage balance, tends towards "eco-tourism," looking out for the future generations by protecting ecological balances, highlighting the social valueidentity, increasing the regional income, and suggesting the sustainability of local development. Suggestions are developed for the integration of the "Dadia EcoTourism Area" in the Dadia Forests in the city of Soufli in Greece in the Dadia settlement. Following the literature review regarding eco-tourism, environmental analyses of the Dadia settlement and Dadia eco-tourism area have been given a place. The physical potentials of the areas have been determined as a result of analyses, including on-site observation, interviews with users, photographing and mapping works. Within the scope of these potentials, suggestions regarding the economic and social integration have been developed, such as the inclusion of the settlement within the parkour routes, assessment of unused building stock, and increasing the sportive-cultural action variety.

Keywords: Eco-tourism, Dadia, Integrated Tourism Potentials

\section{Introduction}

The dimensions of tourism are increasing day by day and have important positions in state economies, parallel to the rapid economic, political and technological developments and changes in the world. All kinds of development activities conducted in the tourism sector give an action to the economy and form a reviving impact. According to the World Tourism Organization (WTO), International tourist arrivals are forecast to reach 1.8 billion by 2030 according to the newly released UNWTO long-term forecast, Tourism Towards 2030 (UNWTO, 2011). As the number of tourists increases, the activity types they select during their trips also vary. In addition to the continuation and growth of the traditional tourism (mass tourism), new tourism types reveal the sustainability approaches of the New Age (Hawkins and Lamoureux, 2001).

The concept of Eco-Tourism has become popular by coming to the fore with discussions of sustainability and an increase in the importance of tourismenvironment relations in the Brundtland report titled "Our Common Future,"

\footnotetext{
* Assistant Professor, Trakya University, Faculty of Architecture, Department of Architecture, Turkey.

* Instructor, Trakya University, Faculty of Architecture, Department of Architecture, Turkey.
} 
and it has started to be used frequently (WCED, 1987). Eco-tourism, which developed in the 1990s as an alternative and reaction to mass tourism (Butler, 1990; Wheeller, 1991; Zell, 1992; Pleumarom, 1993; Wheeller, 1994; Glasson et al., 1995, Kisa Oval1, 2007), includes elements of rural and cultural tourism. It is also expressed as the most convenient tourism type that could be developed in delicate natural and cultural areas. Eco-tourism is seen as an important tool in the provision of sustainable development against the damages of mass tourism on the environment and society (Fennell, 1999; Kisa Oval1, 2007). Eco-tourism is used in the same meaning as sustainable tourism, and it is one of sustainable tourism's primary methods. Eco-tourism protects the environment, gives importance to the wealth of the local people, and is sensitive towards natural areas (Honey, 1999). Thanks to sustainable tourism policies, eco-tourism has a chance of existence and improvability. Now the togetherness of ecology and economy is considered as a whole, and the conducted activities should improve both economic and ecological productivity together (Fennell, 1999).

Eco-tourism is defined as "a complex phenomenon containing the integration of many actors including the tourists, residing people, suppliers, managers and multiple functions" (Ceballos-Lascuráin, 1993). Furthermore, these actors or shareholders are in a symbiotic relationship uniting under the eco-tourism idea as a tool for economic development and protection of natural resources (Backman et al., 2001).

If eco-tourism industry is to become more developed and sustainable for future generations, it is necessary to establish the connections between settlements and eco-tourism implementations (Backman et al., 2001). This necessity has been determined as the main problem of the study. The fact that Greece could not integrate with the "Dadia Eco-Tourism" area in the neighborhood (500m south) of the "Dadia settlement" in Soufli, and also the fact that both systems cannot support each other in the desired level, is problematic in terms of the sustainability of the eco-tourism industry.

\section{Literature Review}

Eco-tourism is a rapidly developing tourism type within the tourism industry. Especially changes in the structure of the international demand, increases in educational, and increases in interest and consciousness towards environmental issues encourage demand for eco-tourism trips. Despite the fact that the concept of eco-tourism is new, the activities taking place within the scope of this tourism type have been conducted for a long time. Eco-tourism is important in terms of taking these activities under a discipline via the principles it brings. The declaration of the year 2002 as "International Eco-Tourism Year" by the United Nations was an indicator of the rising importance of eco-tourism (Demir and Çevirgen, 2006). When the reasons for eco-tourism are examined, we see that negative environmental impacts are dominant. The environmental problems experienced within specific years and their integration with tourism are mentioned in Table 1. 
Table 1. Environmental Problems and the Reasons for the Occurrence of Ecotourism

\begin{tabular}{|l|l|l|}
\hline Periods & \multicolumn{1}{|c|}{ Environmental Problems } & \multicolumn{1}{c|}{ Tourism } \\
\hline $1950 \mathrm{~s}$ & Benefit and use & $\begin{array}{l}\text { Mass tourism beginning in } \\
\text { exploration and interest period }\end{array}$ \\
\hline $1960 \mathrm{~s}$ & $\begin{array}{l}\text { Consciousness,the interest and protests } \\
\text { of public }\end{array}$ & $\begin{array}{l}\text { Development, growth and } \\
\text { environment components as } \\
\text { attraction }\end{array}$ \\
\hline $1970 \mathrm{~s}$ & $\begin{array}{l}\text { Institutionalization, the establishment } \\
\text { of the department of environmental } \\
\text { protection in the USA, visible pollution } \\
\text { and anxiety such as air and water } \\
\text { pollution }\end{array}$ & $\begin{array}{l}\text { Marketing in the growth and } \\
\text { success period. Studies of } \\
\text { academicians in the issue of } \\
\text { the enviromental impacts }\end{array}$ \\
\hline $1980 \mathrm{~s}$ & $\begin{array}{l}\text { Anxiety regarding the toxine materials } \\
\text { in environment, the problem of heating } \\
\text { and the tearing of the ozone layer of the } \\
\text { world }\end{array}$ & $\begin{array}{l}\text { Widening world market and } \\
\text { technological growth }\end{array}$ \\
\hline $1990 \mathrm{~s}$ & $\begin{array}{l}\text { Destruction of forests, climate changes, } \\
\text { desertation, global warming }\end{array}$ & $\begin{array}{l}\text { Occurrence of eco-tourism and } \\
\text { sustainable development }\end{array}$ \\
\hline $2000 \mathrm{~s}$ & $\begin{array}{l}\text { Destruction of nature and water } \\
\text { resources.Climatic problems increasing. }\end{array}$ & $\begin{array}{l}\text { Sustainable tourism plannings } \\
\text { and ecological approaches. }\end{array}$ \\
\hline
\end{tabular}

Source: adapted from L. E. Hudman, 1992.

The first official definition of eco-tourism was made by Lascurain in 1987. Lascurain defines eco-tourism as "travelling to relatively undisturbed or uncontaminated natural areas with the specific objective of studying, admiring, and enjoying the scenery and its wild plants and animals, aswell as any existing cultural manifestations (both past and present) found in these areas." While the definitions of Ceballos-Lascuráin (1987) and Boo (1990) tend to emphasize the nature-based experiences sought by the tourist, current definitions tend to emphasize various principles related to the concept of sustainable development. Wight (1993) draws attention to the nature-based education aspect of sustainable eco-tourism. Although this approach has not been clearly stated in the previous discussions, the concept has clearly turned into a normative pattern in the last decade. The eco-tourism definitions within the development process and the relation of the definitions with the basic concepts are given in Table 2. 
Table 2. Selected Definitions of Ecotourism

\begin{tabular}{|c|c|c|}
\hline Source & Definition & $\begin{array}{l}\text { Main Related } \\
\text { Concepts }\end{array}$ \\
\hline $\begin{array}{l}\text { Ceballos-Lascuráin, } \\
1987\end{array}$ & $\begin{array}{l}\text { Travelling to relatively } \\
\text { undisturbed or uncontaminated } \\
\text { natural areas with the specific } \\
\text { objective of studying, admiring, } \\
\text { and enjoying the scenery }\end{array}$ & Nature-based \\
\hline Fennel and Eagles, 1990 & $\begin{array}{l}\text { Local people, resource } \\
\text { management and tour operators } \\
\text { are the necessary components of } \\
\text { an eco-tourism development } \\
\text { model. }\end{array}$ & $\begin{array}{l}\text { Relation between } \\
\text { protection and service }\end{array}$ \\
\hline $\begin{array}{l}\text { The Ecotourism } \\
\text { Society, } 1991\end{array}$ & $\begin{array}{l}\text { Responsible travel to natural } \\
\text { areas which conserves the } \\
\text { environment and improves the } \\
\text { well-being of local people }\end{array}$ & $\begin{array}{l}\text { Giving importance to } \\
\text { the benefit of the local } \\
\text { people }\end{array}$ \\
\hline $\begin{array}{l}\text { Ecotourism Association } \\
\text { of Australia, } 1992\end{array}$ & $\begin{array}{l}\text { Ecologically sustainable tourism } \\
\text { that fosters environmental and } \\
\text { cultural understanding, } \\
\text { appreciation and conservation }\end{array}$ & Ecologic sustainability \\
\hline $\begin{array}{l}\text { National Ecotourism } \\
\text { Strategy of Australia } \\
\text {,Allcock et al., } 1994\end{array}$ & $\begin{array}{l}\text { 'natural environment' includes } \\
\text { cultural components and that } \\
\text { 'ecologically sustainable' } \\
\text { involves an appropriate return to } \\
\text { the local community }\end{array}$ & $\begin{array}{l}\text { Related to } \\
\text { sustainability and } \\
\text { ecology }\end{array}$ \\
\hline Norris, 1994 & $\begin{array}{l}\text { This kind of tourism is not } \\
\text { tourism as long as the provision } \\
\text { of local economic benefits and the } \\
\text { protection of resources are not } \\
\text { carried out together. }\end{array}$ & $\begin{array}{l}\text { Related to protection } \\
\text { and local economy }\end{array}$ \\
\hline Weaver, 1999 & $\begin{array}{l}\text { Eco-tourism has a sustainable } \\
\text { character due to being nature- } \\
\text { based and supporting natural and } \\
\text { cultural resources. }\end{array}$ & Being sustainable \\
\hline Sinclair, 2005 & $\begin{array}{l}\text { What attracts the tourists in eco- } \\
\text { tourism is to know the factors } \\
\text { such as plant, animal, } \\
\text { extraordinary properties, history } \\
\text { and culture; and it is very } \\
\text { important to reveal their } \\
\text { potentials. }\end{array}$ & $\begin{array}{l}\text { Determination of the } \\
\text { potentials }\end{array}$ \\
\hline Campbell, 2007. & $\begin{array}{l}\text { Travel to enjoy the world's } \\
\text { amazing diversity of natural life } \\
\text { and human culture without } \\
\text { causing damage to either }\end{array}$ & $\begin{array}{l}\text { Planning of ecologic } \\
\text { sustainability by } \\
\text { protecting the } \\
\text { environmental values }\end{array}$ \\
\hline
\end{tabular}

Source: adapted from Blamey, 2001 and K1sa Ovalı \&Tachir, 2015 
Although there are different definitions for eco-tourism in the literature, analysis of the basic definitions shows that eco-tourism can be represented under three main concepts;

- Nature-basedness (action variety and protection)

- Environmentally-educated tourists (awareness)

- Sustainable planning (sustainable development)

Eco-tourists, or the actual customers of eco-tourism, consist of people who love travelling to natural areas and cultural environments and who want to understand and learn local cultures. The reasons and aims of ecotourists are integration in natural and rural life, social interaction, knowing, recognition, exploration, education, scientific curiosity, information, search for risk, selfdiscovery, self-realization, knowing the value of nature in theoretical meaning in eco-tourism, watching the nature, using without any disturbance, integration with nature, enjoying nature in a way, causing to the least negative impacts on the environment, active cohesion with local people and providing economic benefits for the local society (Erdoğan, 2003; Kisa Oval1, 2007).

Sustainable planning is nature-based and includes also environmental education. It is necessary to evaluate the ecologic and economic decisions together for an environmentally compatible life with sustainable development. Within this scope, the protection of natural areas as tourism areas for the future, but those protected from the negative environmental impacts of tourism could be realized with decent eco-tourism plannings (Özbey, 2002). Ecotourism is an area that is mostly dependent on efficient planning and policy development. For this reason, eco-tourism planning covers many actions, participants, information areas, decision-making processes, and implementation levels (Branch, 1985). According to Gunn (1994), the comments of operations, local people and government should be combined, and they should be taken into consideration as a whole with eco-tourism planning, in which the campus and tourism area integrate with an interactive approach.

\section{Methodology}

In this study, which utilizes both qualitative and quantitative research methods, suggestions are developed for the integration of "Dadia Eco-Tourism Area" taking place in the natural protected area of Dadia Forests near the city of Soufli. Within this scope, following the literature review regarding the ecotourism, environmental analyses of Dadia settlement and Dadia eco-tourism area have been given a place. The physical potentials of the areas have been determined as a result of specific analyses, including on-site observations, interviews with users, photographing and mapping works. Suggestions regarding economic and social integration have been developed, such as the inclusion of the urban settlement within the parkour routes, the assessment of unused building stock (hostel, rent a room atc.), and an increase of the sportive-cultural 
action variety (festivals and activities atc). In this context, the created with process of integration model will provide two fields to work together.

\section{Dadia Forests: General Specifications}

The Dadia Forests are in the province of Evros in the eastern Macedonian and Thracian region of north east Greece. This is an ecological area in which natural eco-system cycles are seen. It has been protected as a national park with the cooperation of INCN/WWF since 1980. The total protected area of Dadia Forests is $42.460 \mathrm{~h}$. and a $7.290 \mathrm{~h}$. core region of the forests is defined as an "Absolute Nature Reserve/Wild Area," in which all usages are forbidden (IUCN, 1994-www.gnto.gr, 2016), (Figure 1-2).

Figure 1. The Location of Dadia Forests in Greece
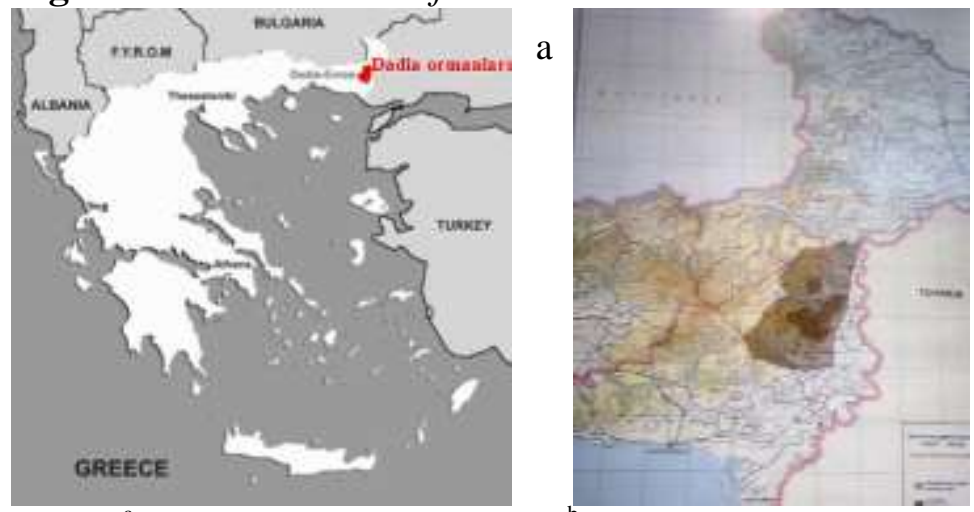

$\mathrm{b}$

Source: ${ }^{\mathrm{a}}$ www.greecemap.com, 2016, ${ }^{\mathrm{b}}$ Dadia ecologic tourism museum archive, 2017

Figure 2. Dadia Forests
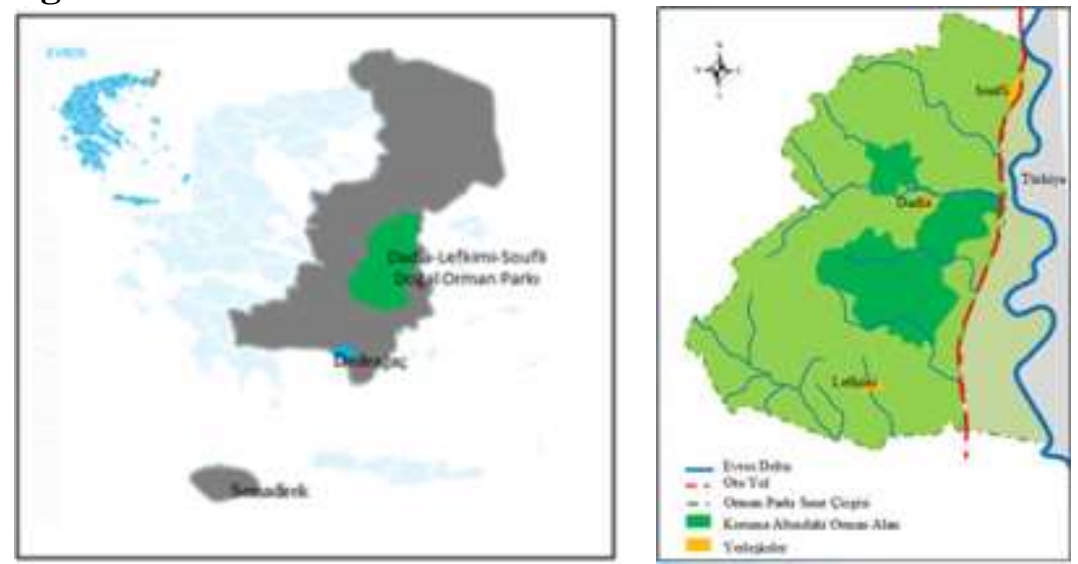

Source: www.dadiamap.com developed Tachir,2016

Dadia Forests exists in the intersection of Asia and Europe and near the eastern migration route of many bird species. The forests provide shelter for many bird species belonging to Asian and European flora and fauna. It is one of some rarely found shelters in which 36 out of 38 raptors in Europe are seen. 
Some of these raptors pass from Dadia Forests during migration, and some of them spend the winter in the forest. There are almost 20 types of nests in the forests. This area also provides shelter for 3 out of 4 European Vultures (Black Vulture, Scavenger Vulture and Griffon). Black vultures are the last colonies of their species, and they reside in Dadia Forests. The reason why the fourth species, Lammergeyer, visits these forests is that it can easily find food (carrion) for itself in the forest (Svoronou and Holden, 2005).

The forest area has been shaped with Maritza and rough land structure. The ecological importance of the region is not limited to raptors. In terms of flora variety, the forest is covered with maquis bush, as well as piney wood and mature forests. The forest area is covered with Turkish Pine (Pinus brutia) (Quercus spp.) mixed with Pinus nigra and oak. Greek Strawberry trees (Arbutus adrachne), Sclerophyllous bushes, Phillyrea (Phillyrea latifolia), Treeheath (Erica arborea) and Cistus creticus can be found in the south west region of the forest. The forest also contains little rivers, small areas, grasses and rocks (mostra). It has been observed that 219 bird species, 40 different types of reptiles and frogs, and 48 mammal species exist in the forest with the unique eco-system cycle (Skartsi and Poirazidis, 2002).

About 360-400 plant species have been recorded in the protected region until today. "Minuartia greuteriana" and "Onosma" kittanae, which are flower types, are seen in the area as two endemic species. In addition, "Cephalanthera epipactoides," "Salix xanthicolakai," and "Zygophyllum album," which are three rare flower types, also are in this forest area. Furthermore, 25 orchid species, especially a very rare species called "Eriolobus trilobatus," are observed in this area. 29 types of plant species in wild apple tree types are under protection (http://dadia-np.gr, 2017).

The following areas in Dadia Forests host these unique natural formations:

1. Dadia Settlement (Urban Area)

2. Dadia Eco-Tourism Center

Figure 3. Locations of Settlement Units

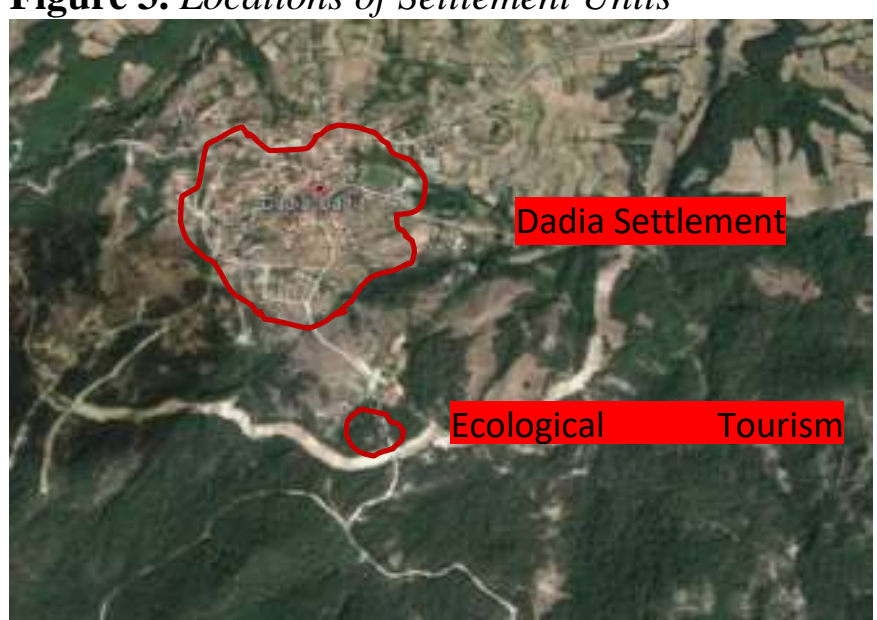

Source: www.google.earth.com,2017 


\section{Field Study: Dadia Settlement (Urban Area)}

The Dadia Settlement sits at a $282 \mathrm{~m}$ altitude and is $14 \mathrm{~km}$ to the city of Soufli. It is a natural settlement area with genuine character. It is takes its name from Dadia Forests with unique natural beauties. This urban settlement, taking place right at the beginning of Dadia forests, is the most popular eco-tourism destination in Greece (Hovardas and Stamou 2006).

When the natural geomorphologic land properties of the area are examined, we find volcanic rocks and neogene formation rocks rich in minerals in the region. The northern part of the area, consisting of two main geological zones, contains chalcogen volcanic and sedimentary rocks, which experienced intense erosion. The southern part of the area contains rock outcrops and complex land formations (Figure 4).

Figure 4. Geo-morphologic Properties of Dadia

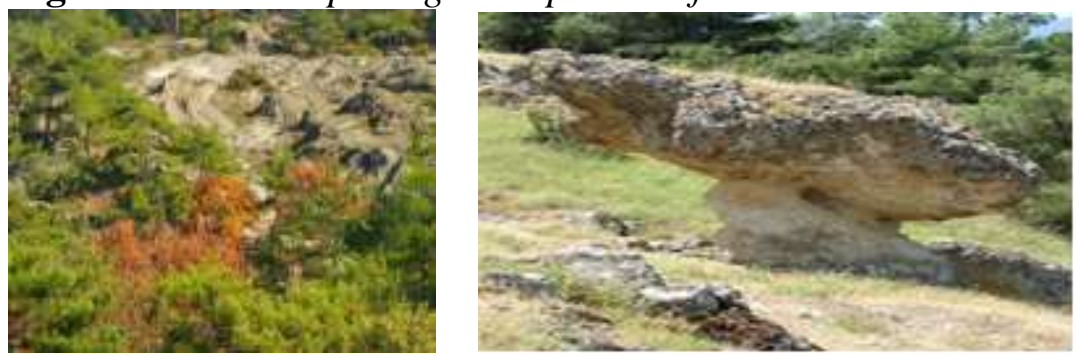

Source: www.atlasvisual.com/dadia-greece-thrace, 2017

The land is characterized by various hydrographic networks with small and big rivers, as well as little and big valleys, and plain and steep slopes. The highest hill of the National Park is Kapsalo hill at 620m (Figure 5). The topographic structure and locations of the settlement between the settlement and Natural Park can be seen in Figure 5.

Figure 5. Land Properties
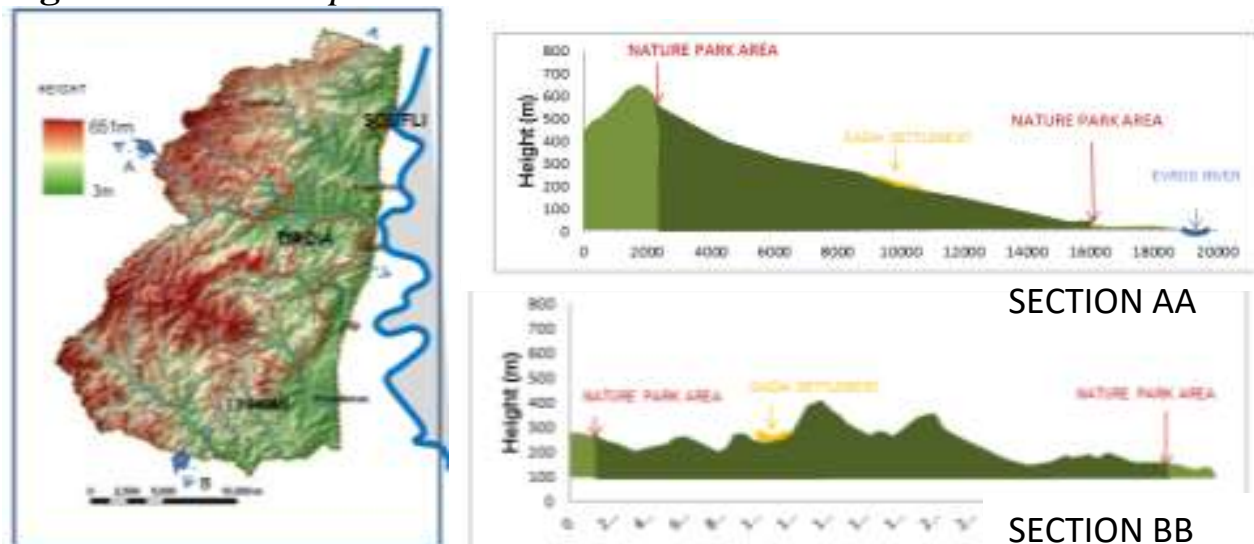

Source: Catsodorakis -developed Tachir, 2017

The Dadia Settlement is a village with 200 houses and a population of 533, according to the census in 2011. Local people primarily retired and old 
individuals deal with farming, bee culture, animal breeding, and forestry for additional income. Much of the young population emigrates, because the area does not have business opportunities (interview local people, 2017). When the built environment analyses of the settlement are examined, we see that there is dispersed settlement, depending on the rural area character. The settlement area is limited to the forest and agricultural lands. The transportation network has an organic character. The roads consist of double lanes ( $7 \mathrm{~m}$ wide), and there is no pedestrian road. The urban framework of the area is positioned in the center of the settlement. The housing settlement has been planed in a dispersed and discrete order, depending on the center. Generally, the houses whose construction is reinforced concrete have one or two stories (Table 2a-2b).

Table 2a. Built Environment Analyses of Dadia Settlement

\begin{tabular}{|c|c|c|}
\hline & Analyses & Deductions \\
\hline  & & $\begin{array}{l}\text { - A settlement with an } \\
\text { orientation towards the } \\
\text { centrum accepted as the } \\
\text { center } \\
\text { - All the structures are in } \\
\text { discrete order as an } \\
\text { urban area }\end{array}$ \\
\hline 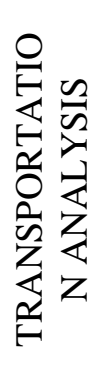 & & $\begin{array}{l}\text { - Transportation network } \\
\text { of the settlement has an } \\
\text { organic character } \\
\text { - Roads consist of double } \\
\text { lane }(7 \mathrm{~m}) \\
\text { transportation networks } \\
\text { - There is no pedestrian } \\
\text { road }\end{array}$ \\
\hline 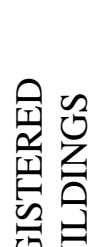 & & $\begin{array}{ll}\text { - } & \text { Square Church } \\
\text { - } & \text { Municipality } \\
\text { - } & \text { Primary School } \\
& \text { Building } \\
\text { - } & \text { Chapel }\end{array}$ \\
\hline
\end{tabular}

Source: Tachir, 2016 
Table 2b. Built Environment Analyses of Dadia Settlement

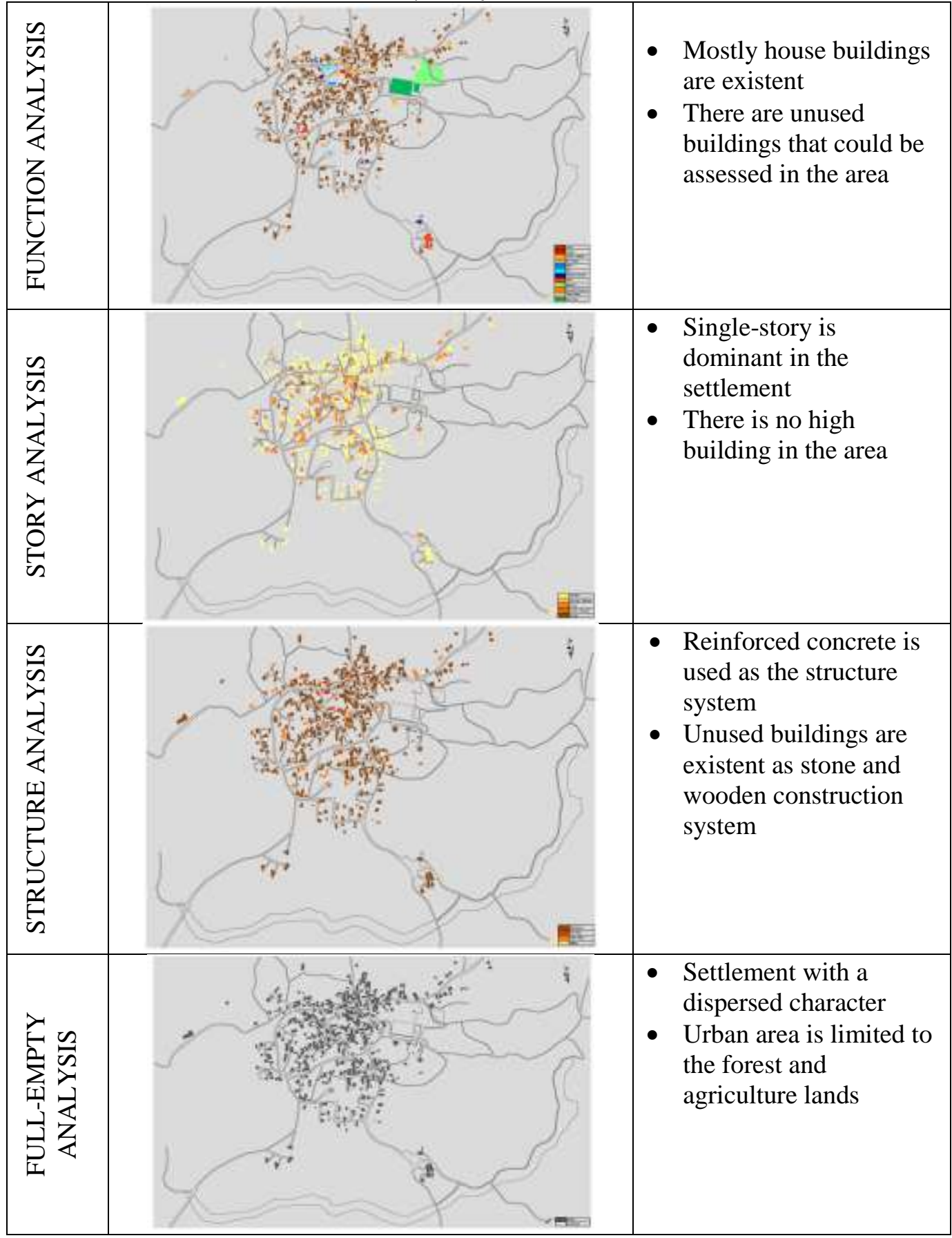

Source: Tachir, 2016

\section{Dadia Eco-Tourism Center}

An office of the World Wildlife Protection Foundation (WWF) was established in 1980 for the purpose of protecting and developing this area. The foundation, in an effort to provide sustainability and economic wealth to the 
Dadia region, decided to construct the "Dadia Eco-Tourism Center" to be the focal point of the area for visitors. The center was completed in 1988. The Dadia Eco-Tourism Center (DNP: Dadia Natural Park) was planned in a way that it includes an information building, accommodation unit, birdwatching area, and pedestrian parkour routes (Figure 3).

Tourism in Dadia area has firstly been assessed within the scope of few visitors within the frame of the theories regarding nature protection. At the beginning of the 1990s, the main visitor infrastructure was established, and the area started to develop as an eco-tourism destination. While the number of visitors coming to Dadia was 10243 in 1995, this number increased to 50.592 in 2003. There was an increase of $394 \%$ in the eight-year period (Svoronou and Holden, 2005). Within a general process evaluation, it is seen that there has been a regular increase in the number of tourists from 1995 until the 2000s. However, a partial decrease was seen in the number of tourists in 2001 , and after that, the rising curve sustained until 2003. Following this, another decrease was experienced. We also see that the highest number of tourists came to Dadia in 2003 (approximately 50.000) as an impact of the declaration of the year 2002 as an eco-tourism year by the UN. In the following years, the number of tourists decreased, though the number remained stable after the final decrease in 2006. The attained data are limited to the year 2008, with the number of tourists visiting the area a little above 40.000 (Table 3 ).

Table 3. Number of Tourists according to years

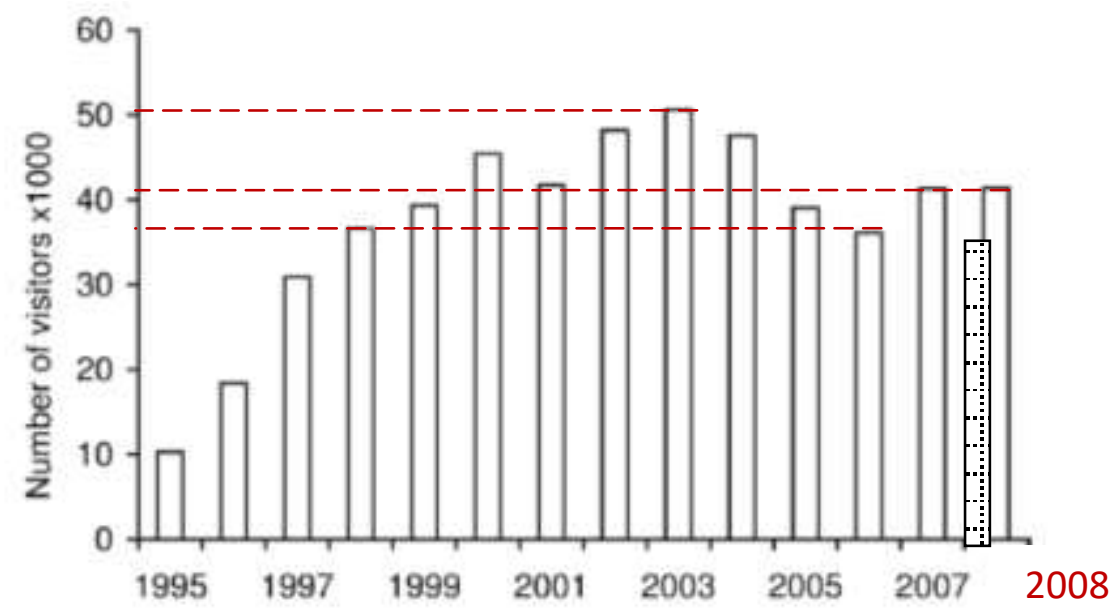

Source: Liarikos, 2010

When the distribution of the number of the tourists (with an acceptance of 40.000 tourists on average) to the months in 2008 and the densities are considered; it is observed that the eco-tourism area has been parallel to the movement in world tourism and it has experienced its most intensive period in August. Although May has also become intensive after that; the lowest number of visitors are seen in January and February. The numbers include domestic and foreign tourist information and the information of how many of them are 
domestic tourists and how many of them are excursionists could not be reached (Table 4).

Table 4. The Number of Visitors coming to the Area according to the Months in 2008

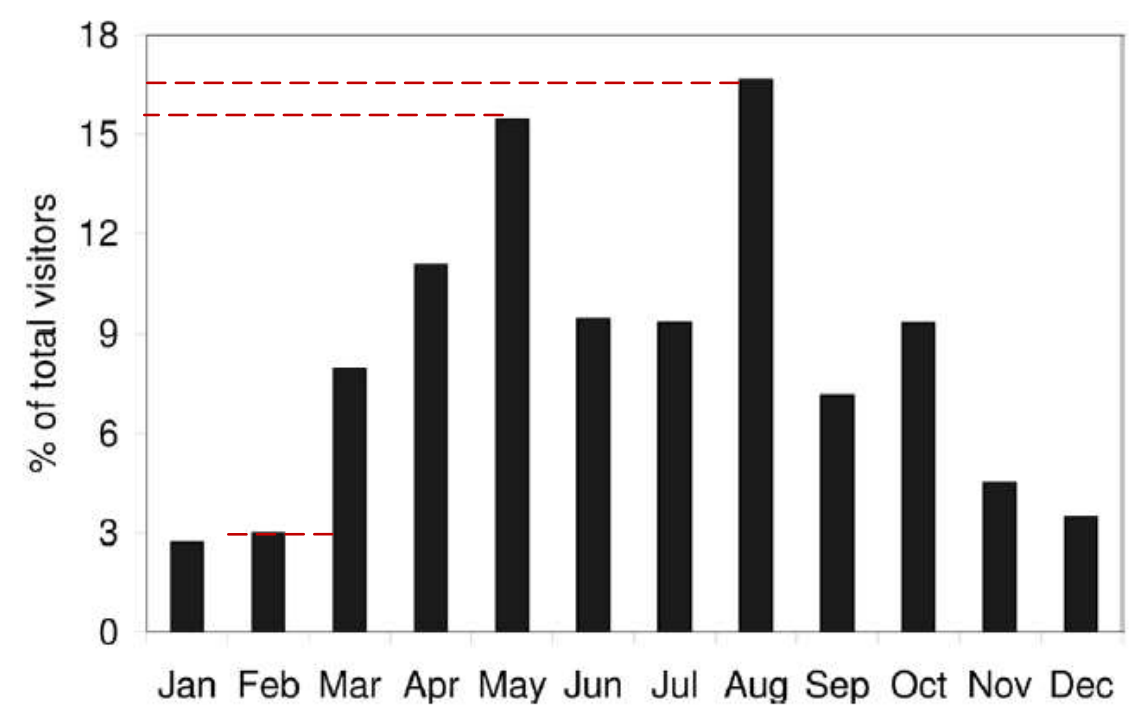

Source: Liarikos, 2010

The Eco-Tourism Information center is in the entrance of the area. The building is a two-story, reinforced, concrete structure with a gallery showcasing a museum, publicity cinevision hall, and souvenir sale hall (Figure 6).

\section{Figure 6. Dadia Eco-Tourism Center}
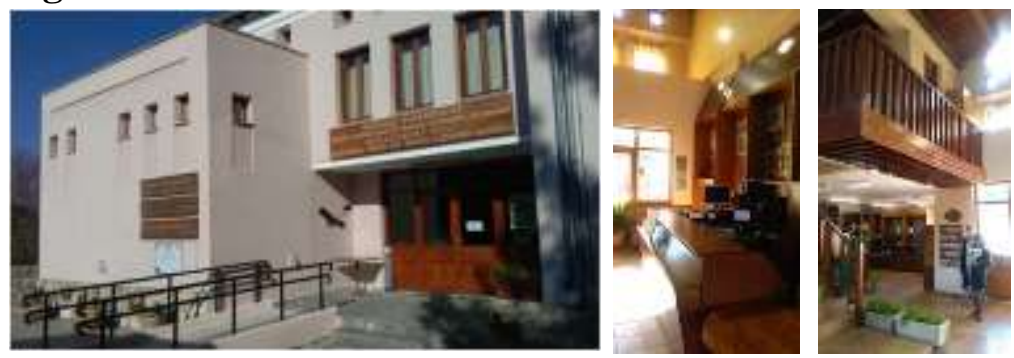

Source: Original, Tachir, 2017

Eco-Tourism Hotel completed and coming into service in 1990 takes place near the ecologic information center. The hotel is a single-story reinforced concrete structure with a cafeteria and 20 rooms with an accommodation capacity of maximum 40 people (Figure 7 ).

Although there are domestic excursionist visitors in the eco-tourism area (their number is not known), mostly there are foreign tourists in the hotel. The hotel serves with complete fullness the daily maximum of 40 people, especially in April, May, June, July and August. The number of tourists residing in the hotel in other months of the year is scarcely any (Georgitsi, 2017). These data 
show that the Eco-Tourism Hotel is intensively used in five months of the year, and thus the accommodation system should be supported within these months.

Figure 7. Dadia Eco-Tourism Hotel

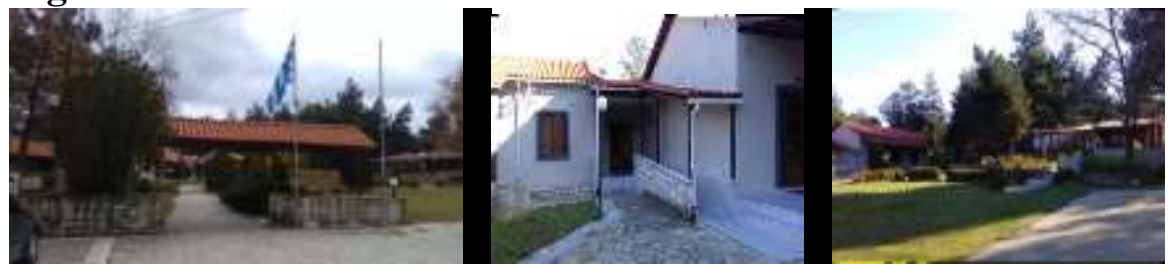

Source: Original, Tachir, 2017

The Birdwatching is established in 1994 within the scope of eco-tourism activities is a single-story wooden structure with a lean-to roof which is $3,5 \mathrm{~km}$ away from the Information Center. Trips are arranged with minibuses, which have a capacity of 14 people and move once every 20 minutes from the center each day of the week. On average, 13 tours are made to the area in a day and a maximum of 182 (13 people x14 tour) people visit the area. Information regarding whether the carrying capacity of the area has been taken into consideration in the organization of the tour numbers could not be accessed. It is possible to observe the vultures among the raptors from the birdwatching observatory. First, information is given to the tourists about the vultures and then binoculars are given to them to conduct observation (Figure 8).

Figure 8. Birdwatching Place

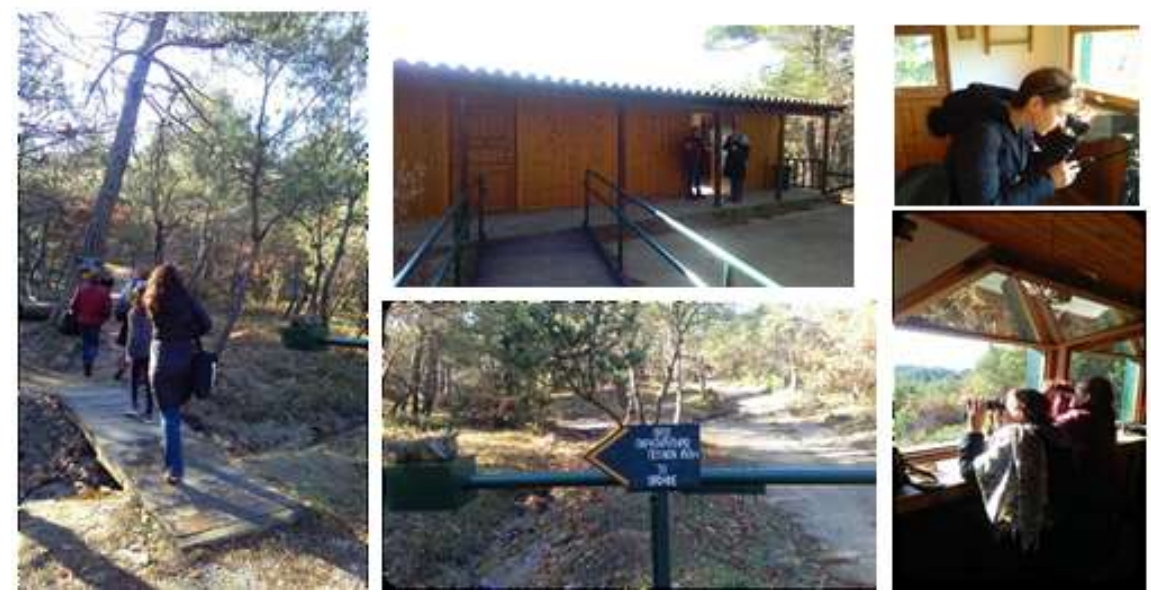

Source: Original, Tachir, 2017

Pedestrian Parkour Lines have been arranged as four different natural walking lines whose difficulties and lengths are different and which have been organized within the scope of nature walking and nature observation as ecotourism activities (Figure 9, Table 3). 
Figure 9. Four Different Walking Parkour Lines

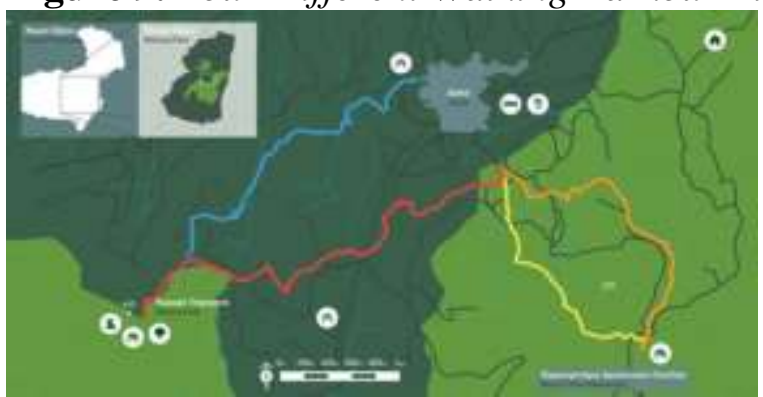

Source: www.dadia-np.gr,2016

Table 3. Parkour Routes

\begin{tabular}{|c|c|}
\hline Parkour Names & Parkour routes \\
\hline $\begin{array}{l}\text { nOPTOXWW } \\
\text { cawce IR }\end{array}$ & $\begin{array}{l}\text { This is a parkour that includes paths with little hardship and } \\
\text { slight slopes. It starts from the Information Center and } \\
\text { finishes at the birdwatching observatory. The parkour is } 3,5 \\
\mathrm{~km} \text { and its completion takes almost } 60 \text { minutes. People can } \\
\text { walk in the old carriage road passing inside the forest and the } \\
\text { unique vegetation, traces of great and little mammals, } \\
\text { blackstork flying above the rocks, brachydactylic eagle, } \\
\text { sparrowhawk, hawk and other birds could be seen in this } \\
\text { parkour. }\end{array}$ \\
\hline $\begin{array}{l}\text { KITPNO } \\
\text { ogavo }\end{array}$ & $\begin{array}{l}\text { This parkour turns back from the birdwatching observatory to } \\
\text { the information center. The parkour has a light slope of } 2.5 \\
\mathrm{~km} \text { and it takes } 45 \text { minutes. The old carriage path going down } \\
\text { the lira river from the fields in the parkour is followed. In this } \\
\text { path, the wild flowers growing in the forest could be seen. } \\
\text { Also; the little birds, Finch, Canker and Woodpecker voices } \\
\text { around the area could be heard. }\end{array}$ \\
\hline & $\begin{array}{l}\text { The parkour starting from the information center finishes at } \\
\text { the hill of Gibrena mountain taking place in } 520 \mathrm{~m} \text {. It is a } \\
\text { parkour ascending upwards. This parkour taking } 150 \text { minutes } \\
\text { is } 4.7 \mathrm{~km} \text {. Black glass and acorn trees could be seen in this } \\
\text { parkour. Colorful flowers in the open grasses before reaching } \\
\text { Gibrena hill, Byzantine ruins on the hill and panoramic view } \\
\text { of Dadia front could be watched. }\end{array}$ \\
\hline 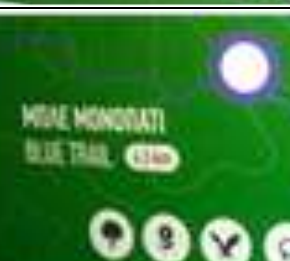 & $\begin{array}{l}\text { It is the road back from Gibrene mountain, it takes } \\
\text { approximately } 90 \text { minutes and it is } 4.5 \mathrm{~km} \text {. The parkour } \\
\text { passes inside the forest during the walk and Oak, Hornbeam, } \\
\text { Kumara, Matey, Shrub and many other bushes and wild } \\
\text { flowers could be seen. The cultivation areas are reached by } \\
\text { following Diavlorema river. }\end{array}$ \\
\hline
\end{tabular}

Source: www.dadia-np.gr, 2016

\section{Findings}

In areas of eco-tourism the comments of operations, local people, and the government should be combined so that plans can be made which the settlements 
and tourism areas can support. These should integrate with each other within the scope of an interactive approach. Although the Dadia Eco-Tourism Area takes place in a $500 \mathrm{~m}$ walking distance to the settlement, it has not integrated with the campus. The following problems have been detected as a result of the individual interviews, observations and analyses within the field study:The settlement is used only as a transition (transportation line),tourists cannot be attracted to the settlement, the cafeteria cannot provide alternative food variety, the local people cannot get economic benefits,entrepreneurship is low because of the age profile of the local people,emigration of young people is high due to unemployment and accommodation capacity is insufficient for the high season.

At this point, the main problem is that the settlement and the eco-tourism area do not support each other in economic and social terms. Three options for integration could solve this problem:

1. The inclusion of urban settlement in the parkour routes (increasing the socio-cultural interaction, attracting the tourists to the settlement)

2. Assessment of the unused building stock (prevention of additional structuring in terms of accommodation support)

3. Increasing the sportive-cultural action variety (using the urban potentials, economic income)

1. Urban settlement should be included in the parkour routes. The walking routes on the yellow, orange, red and blue paths are inside the forest area. The tourist profile of eco-tourism desires the dialogue with local people, so that social interaction can be enhanced via the stations (the existent restaurants, cafes or stores in the settlement) that can be formed with the transition of parkour routes inside the settlement. This demand can only be realized by attracting the tourists in the social environment. In addition, the economic contribution of the tourists to the local people is important in terms of the development of the place with local dynamics. It can also prevent undesired migration.

2. Unused buildings should be evaluated. 40.000 tourists came in 2008. It could be presumed within the scope of this value that 3333 tourists come to the area on average per month $(40.000 / 12=3.333)$ and 111 tourists come to the area on average per day $(3.333 / 30=111)$ (Table 4). The hotel accommodation capacity will meet the demand for the low season (winter months) within the scope of the information that the tourists visiting the area in this season are generally domestic and excursionist tourists. However; it is also foreseen that the demand formed by the foreign tourists in the intensive season (summer months) will not be able to be met by the supply. The current accommodation supply deficit could be met with the lodging (room renting) in a way that will develop the local economy. In addition, the eco-tourism center could be supported with the evaluation of the unused building stock detected in the built environment analyses. Furthermore, the intensive season will need the support of gastronomy, as well as accommodation, 
and meeting this demand with alternative food operations (local supply) in the settlement is important in terms of integration.

3. Action variety of the sportive-cultural rituals should be increased. There are religious eids and festivals (Dadia Church Day, Monastery Day, Youth Festival and Mushroom Festival) peculiar to the urban area. Moreover, the cultural action variety expected by the eco-tourist could be increased, while ensuring the inclusion of the old population forming the general profile within active urban life by arranging special religious celebration days and festivals.

\section{Results}

Support is necessary under four main areas within the scope of eco-tourism planning. These areas offer a holistic viewpoint in the general assessment, regarding the integration of eco-tourism and the settlement.

Table 3. Process of Integration Model

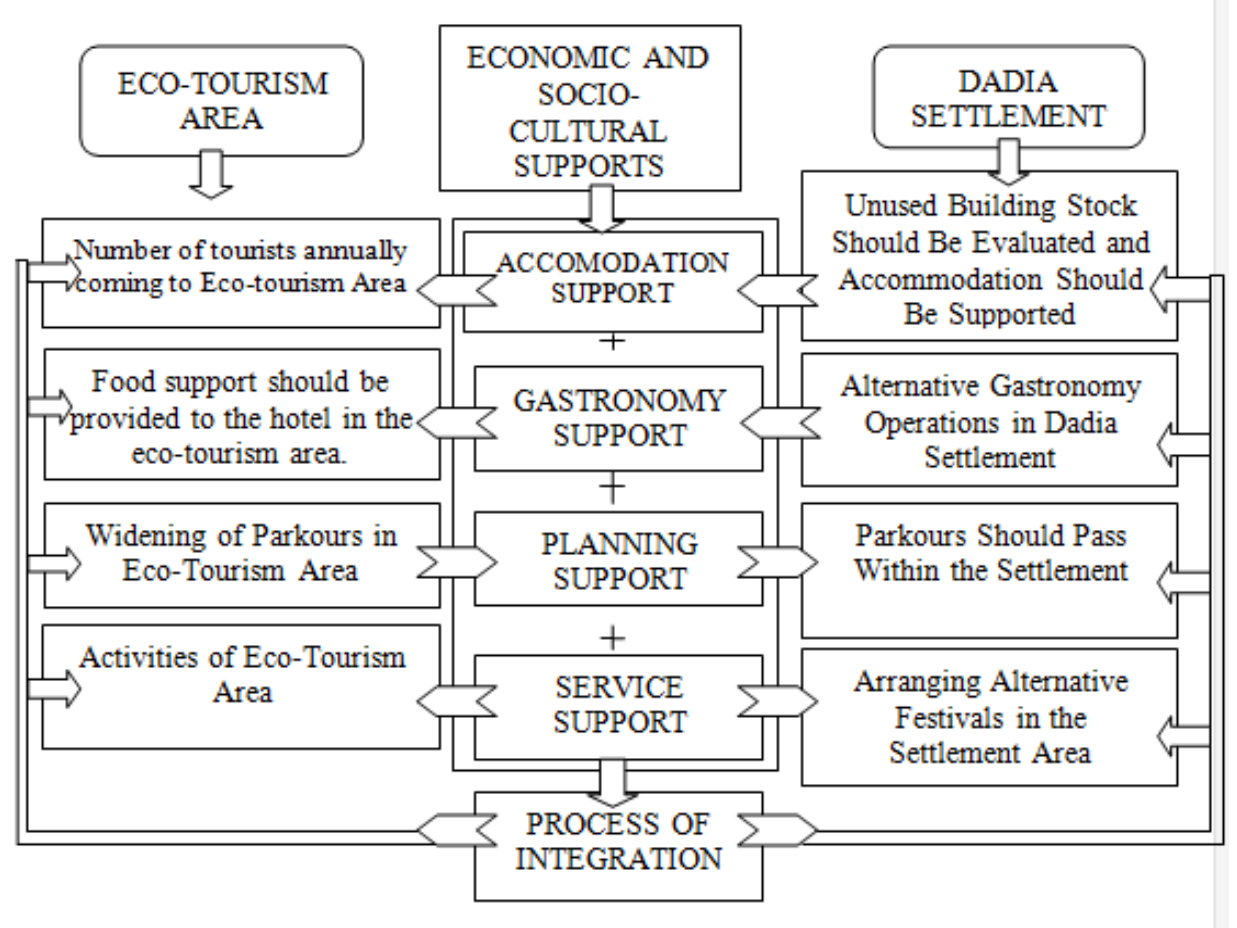

\section{Conclusions}

For the two systems to support each other in a socially and economically desirable way, integration should be provided in the following four headings. These are first, accommodation support: The unused building stocks in the settlement should be considered within the scope of small-scale accommodation. Second, gastronomy support: Service of the operations in the settlement should be provided as an alternative to the hotel cafeteria.Third, 
Planning support: Parkour routes in the eco-tourism area should pass inside the settlement. Fourth, service support: Cultural-sportive potentials of the settlement should be determined and on-site festivals and activities should be arranged. The introduction of them could also be made via WWF as well as municipality.

The organization of the aforementioned supports within the frame of a healthy program will ensure the integration of economical and social aspects of the Dadia Eco-Tourism Area with the Dadia Settlement.

\section{Acknowledgments}

This manuscripts was prepared from the unpublished doctoral thesis, that is titled "A Method for Integration in Coastal Cities for Ecological Tourism in Context of Tourism Potential: Sample of Alexandroupolis" Gildis Tachir to Trakya University Institute of Science conducted by Assist. Prof. PhD.Pinar Kisa Ovalı. This manuscript is original.

\section{References}

Backman S, Petrick J and Wright BA (2001) Management Tools and Techniques: an Integrated Approach to Planning. The Encyclopedia of Ecotourism. CABI Publishing. 28: 451-462. ISBN: 0851993680

Blamey RK (2001) Principles of Ecotourism. The Encyclopedia of Ecotourism. CABI Publishing. 01: 5-20. ISBN: 0851993680

Boo E (1990) Ecotourism: the Potentials and Pitfalls. Washington: World Wildlife Fund. ISBN:0942635140 9780942635140

Branch MC (1985) Comprehensive City Planning: Introduction and Exploration. American Planning Association. Washington, DC: Planners Press. DOI=10.1007 978-94-011-5576-2

Butler RW (1990) Alternative tourism: pious hope or Trojan horse? Journal of Travel Research 28: 40-45. DOI=http://doi/pdf/10.1177/004728759002800310

Catsodorakis G (2010).Introduction.In: Catsadorakis, G. and Källander, H. (eds). The Dadia-Lefkimi-Soufli Forest National Park, Greece: Biodiversity, Management and Conservation. WWF Greece, Athens, 05-29, ISBN: 978-960-7506-10-8

Ceballos-Lascuráin H (1987) The Future of Ecotourism. Mexico Journal January (January): 13-14. DOI= https://doi.org/10.1016/0160-7383(94)90089-2

Ceballos-Lascuráin H (1993) Ecotourism as a worldwide phenomenon. In: Lindberg K and Hawkins D (eds.) Ecotourism: a Guide for Planners and Managers. North Bennington, Vermont: Ecotourism Society, 12-14. ISBN: 0963633104

Demir C, Çevirgen A (2006) Tourism and Environmental Management Sustainable Development Approach, Nobel Publication Distribution, Ankara, (Feb. 2006), 86, ISBN: 9755918450

Erdoğan N (2003) Environment and (Eco) tourism, Pozitif Publication, Ankara (Feb. 2003), 317, ISBN: 9759313022

Fennell DA (1999) Ecotourism: an Introduction. London: Routledge. (November): 315. ISBN: 0-415-20168-3 
Georgitsi D (2017) Dadia Inn Ecotourism Hotel Manager. (March) interview in DadiaGreece.

Glasson J, Godfrey K, and Goodey B, (1995) Toward Visitor Impact Management. Aldershot: Ashgate Publishing, 189.ISBN: 18597205449781859720 547

Gunn CA (1994) Tourism Planning: Basic Concepts and Cases, 3rd ed. New York: Taylor and Francis, 460. ISBN:0844817430

Hawkins DE and Lamoureux K (2001) Global Growth and Magnitude of Ecotourism. CABI Publishing, 4: 63-72. ISBN 0851993680

Honey M (1999) Ecotourism and Sustainable Development: Who Owns Paradise? Washington, DC: Island Press, (Ferbruary): 416. ISBN-10: 1559635819

Hudman EL (1992) Tourism and Environment. Selected Articles in Tourism: 16, Special Issue Tourism and Environment, Istanbul: TUGEV Publication No: 24, 25-34. ISBN: 978-975-482-944-0

Hovardas T and Stamou G.P. (2006) Structural and Narrative Reconstruction of Representations of "Environment," "Nature," and "Ecotourism", Society \& Natural Resources, 19:3, 225-237, DOI=10.1080/08941920500460724

IUCN (1994) Guidelines for Protected Area Management Categories. Gland: IUCN. Greek National Tourism Organisation (2004) Tourist Statistics: 2002, On WWW at http://www.gnto.gr/2/01/eb10000.html. Accessed 08.08.2016

Kisa Ovalı P (2007), A Comparison of Mass Tourism and Ecologic Tourism With Regard To Conceptual, Architectural, and Environmental Impacts, Megaron, YTÜ Faculty of Architecture e-Journal, 2,2:64-79, ISSN: 1309-6915

Kisa Ovalı P, Tachir G (2015) Santorini as a Eco-Destination and 1ts Ecolojical Tourism Potential, Tasarım+Kuram , M.S.Ü. Faculty of Architecture Journal, 11, 20:35-51, ISSN: 1302-2636

Liarikos C (2010). Development trajectories and prospects in the Dadia-LefkimiSoufli Forest National Park.In: Catsadorakis, G. and Källander, H. (eds). The Dadia-Lefkimi-Soufli Forest National Park, Greece: Biodiversity, Management and Conservation. WWF Greece, Athens, 47-62, ISBN: 978-960-7506-10-8

Pleumarom A (1993) What's Wrong with Mass Tourism. Contours: concern for tourism; the quarterly newsletter of the Ecumenical Coalition on Third World Tourism. 6: 15-21. ISSN: 0857-491X

Özbey FR (2002) Sustainable Tourism Development in Globalization Progress. Globalization and Sustainable Development, International Scientific Conference, Book: Varna, 4: 135-150. ISBN: 9786055627263

Scott Campbell (2007) Green Cities, Growing Cities, Just Cities?: Urban Planning and the Contradictions of Sustainable Development. Journal of the American Planning Association 62: 296-312. DOI=10.1080/01944369608975696.

Skartsi T, and Poirazidis K (2002) Management Plan for the Black Vulture in the

Dadia-Lefkimi-Soufli Forest Reserve (unpublished study). Athens: WWF Greece. ISBN :978-960-7506-10-8

Svoronou E, and Holden A (2005) Ecotourism as a tool for nature conservation: the role of WWF Greece in the Dadia-Lefkimi-Soufli Forest Reserve in Greece. J. Sust. Tour. 13: 456-467.DOI= http://dx.doi.org/10.1080/09669580508668573

Tachir G (2016), A Method for Integration in Coastal Cities for Ecological Tourism in Context of Tourism Potential: Sample of Alexandroupolis, unpublished doctoral thesis study, fourth six month study report, Department of Architecture, Trakya University Institute of Science, Edirne/Turkey

Weaver D (1999) Magnitude of ecotourism in Costa Rica and Kenya. Annals of Tourism Research 26,792-816. DOI=10.1016/S0160-7383(99)000 44-4 
Wight PA (1993) Sustainable ecotourism: balancing economic, environmental and social goals within an ethical framework. Journal of Tourism Studies 4: 54-66. DOI=https://www.jcu.edu.au/_data/assets/.../jcudev_012532.pdf

Wheeller B (1991) Tourism's troubled times: responsible tourism is not the answer. Tourism Management, 12: 91-96. ISBN:0851993141

Wheeller B (1994) Ecotourism: a ruse by any other name. In: Cooper CP, and Lockwood A (eds.) Progress in Tourism, Recreation and Hospitality Management. London: Belhaven Press, 7: 3-11. Record Number: 19951803377

World Commission on Environment and Development (WCED) (1987) Our Common Future. Oxford: Oxford University Press, 383. ISBN:019282080X

World Tourism Organization (UNWTO) (2011) Global Tourism Forecasts, Specialized agency of the United Nations. Available at: http://www2.unwto.org.

Zell L (1992) Ecotourism of the future - the vicarious experience. In: Weiler B (eds.) Ecotourism: Incorporating the Global Classroom 1991 international conference papers. Brisbane: University of Queensland, Bureau of Tourism Research, Canberra, 30-35. ISBN: 0642163367

http://dadia-np.gr/?page_id=3134, date of access: 09.03.2017

\section{Figure References}

Figure 1a.www.greecemap.com, [date of access: 18.02.2016]

Figure 1b. 2017. Dadia eco-tourism museum archive, 2016

Figure 2. http://www.malawicichlidhomepage.com/aquainfo/evros_dadia.html [date of access: 07.01.2016]

Figure 3.www.google.earth.com-dadia-[date of access: 03.03.2017]

Figure4.www.atlasvisual.com/dadia-greece-thrace,[date of access: 07.02.2017]

Figure 6-7-8. Tachir, G., 2017, photograph archive

Figure 9. http://dadia-np.gr/?page_id=3134, date of access: 09.03.2017

Table 3. Tachir,G.,2017, photograph archive. 
